DOI: $10.17516 / 1997-1397-2021-14-6-679-689$

УДК $539.3+539.42+519.624+666.982 .24$

\title{
Modelling and Simulation of Deformation and Failure of Reinforced Concrete Beams under Four-Point Bending
}

\author{
Vasily A. Belyaev* \\ Khristianovich Institute of Theoretical and Applied Mechanics SB RAS \\ Novosibirsk, Russian Federation \\ Artem I. Boltaev ${ }^{\dagger}$ \\ Novosibirsk State University \\ Novosibirsk, Russian Federation \\ Research Complex of Technological Support Center LLC \\ Novosibirsk, Russian Federation \\ Luka S. Bryndin ${ }^{\ddagger}$ \\ Khristianovich Institute of Theoretical and Applied Mechanics SB RAS \\ Novosibirsk, Russian Federation \\ Novosibirsk State University \\ Novosibirsk, Russian Federation \\ Sergey K. Golushko \\ Arsenii G. Gorynin \\ Novosibirsk State University \\ Novosibirsk, Russian Federation \\ Vasily P. Shapeev ${ }^{\|}$ \\ Khristianovich Institute of Theoretical and Applied Mechanics SB RAS \\ Novosibirsk, Russian Federation \\ Novosibirsk State University \\ Novosibirsk, Russian Federation
}

Received 10.04.2021, received in revised form 10.06.2021, accepted 20.08.2021

\begin{abstract}
A new mathematical model for the four-point bending of reinforced concrete beams is developed and investigated. The model takes into account multi-modulus concrete behavior, nonlinear stress-strain relationships, and damage evolution. An algorithm for a numerical implementation of the model is proposed. The corresponding boundary value problem is solved by the hp-version of the least-squares collocation method in combination with an acceleration of an iterative process based on Krylov subspaces and parallelizing. Special attention is given to the influence of mathematical model parameters on the results of numerical simulation. The results are compared with experimental data and three-dimensional simulation. A satisfactory agreement is shown.
\end{abstract}

Keywords: reinforced concrete, nonlinear stress-strain relationships, four-point bending, multi-modulus behavior, damage evolution, crack, modelling and simulation.

Citation: V.A. Belyaev, A. I. Boltaev, L.S. Bryndin, S. K. Golushko, A. G. Gorynin, V. P. Shapeev, Modelling and Simulation of Deformation and Failure of Reinforced Concrete Beams under Four-Point Bending, J. Sib. Fed. Univ. Math. Phys., 2021, 14(6), 679-689. DOI: 10.17516/1997-1397-2021-14-6679-689.

\footnotetext{
*belyaevasily@mail.ru https://orcid.org/0000-0001-5901-2880

†boltaev_artem@mail.ru https://orcid.org/0000-0003-1317-9903

‡bryndin-1996@mail.ru https://orcid.org/0000-0002-0211-5800

§s.k.golushko@gmail.com https://orcid.org/0000-0002-0207-7648

ฯa.gorynin@g.nsu.ru https://orcid.org/0000-0002-0250-5008

" shapeev.vasily@mail.ru https://orcid.org/0000-0001-6761-7273

(C) Siberian Federal University. All rights reserved
} 


\section{Introduction}

The widespread use of concrete in mass construction of various structures began in the second half of the 19th century. At the same time, concrete despite having high compressive strength is significantly $(10 \ldots 20$ times) less resistant to tension. For this reason, this limits its use in structural elements subject to tension and bending [1].

Steel fibers reinforcement of concrete can significantly increase the bearing capacity of reinforced concrete (RC) structures. They are widely used in civil, industrial, transport, hydraulic, power plant engineering, shipbuilding and machine construction [1,2]. Advantages of RC include fire-resisting property, durability, high compressive strength, low energy consumption for its manufacture, low operating costs for maintaining RC buildings and structures, good resistance to weathering [3]. However, concrete also has a number of disadvantages. First of all, these include high density and, consequently, heavy weight, high sound and thermal conductivity, high brittleness.

To date, there are several approaches to modelling and simulation of RC structures. The analysis of the stress-strain state (SSS) according to building regulations and rules is widespread [4-7]. Another approach is aimed at taking account of RC behavior features and the development of reduced order models. This is especially important for typical structural elements in the form of beams, plates, and shells [8-10]. The third approach is based on the use of threedimensional finite element modelling and simulation of RC structures taking into account many features of their deformation [11-13]. These approaches differ from each other in accuracy of results, computational time, domain of applicability, number of mechanical tests required for their application and validation.

\section{Problem statement and mathematical model}

Consider the four-point bending of a RC beam with the support span $l$, the thickness $2 h$, and the width $b$. We introduce the rectangular Cartesian coordinate system as shown in Fig. 1. The beam is subjected to two concentrated forces $P$ acting downward parallel to the $z$-axis at the distance $a$ from each of the supports.

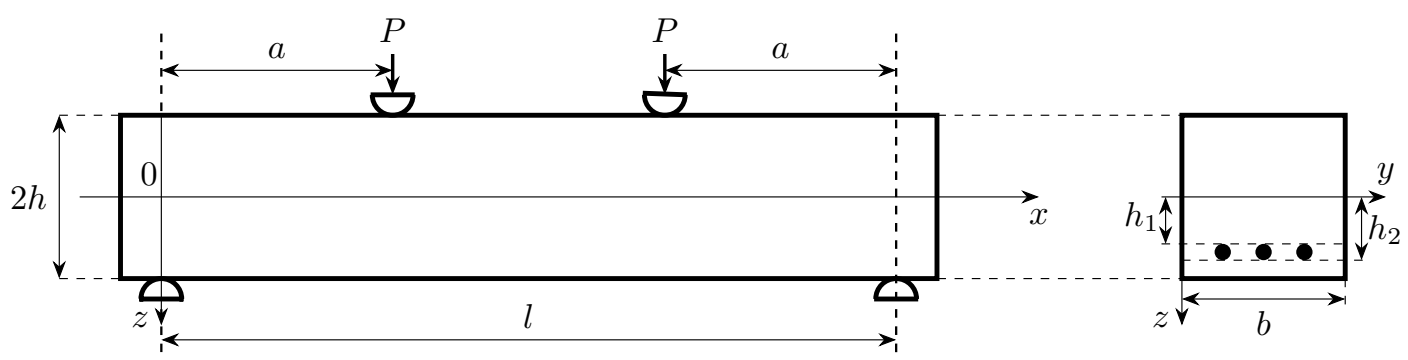

Fig. 1. Four-point bending test scheme of the RC beam (left) and its cross section (right). Black circles denote the reinforcement cross sections

According to [5], it is assumed that the left edge of the beam is hinged, while the right one is simply supported (Fig. 2). The model neglects the shape of the supports and assumes the reactions $R_{A}$ and $R_{B}$ arising at the supports are concentrated. The classical beam theory is used to describe the flexural behavior of the beam. All sought-for values are assumed to be functions of $x$ and/or $z$. The shear force $Q(x)$, the bending moment $M(x)$, and the longitudinal force $N(x)$ are determined on the reference (middle) surface of the beam. The solution of the equilibrium 


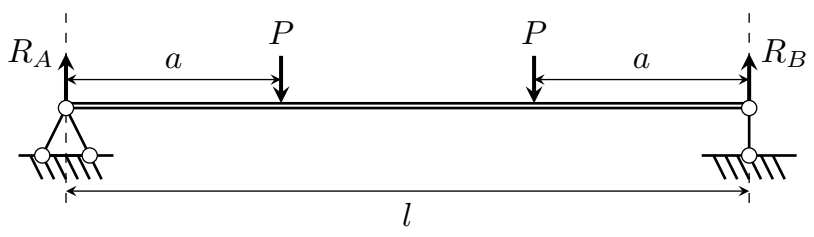

Fig. 2. The scheme of the four-point beam bending model

equations $\frac{d N}{d x}=0, \frac{d Q}{d x}=0, \frac{d M}{d x}=Q$ has the form

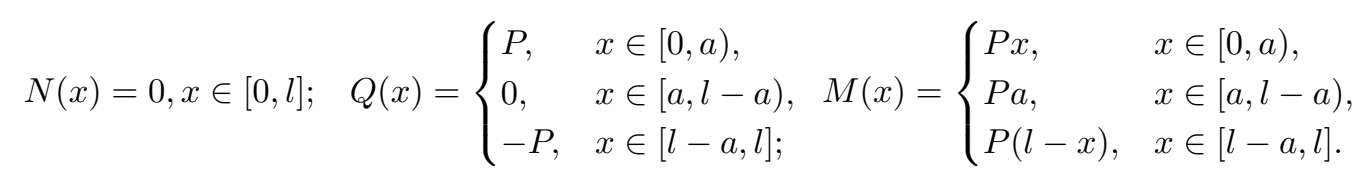

It is assumed that there are no bond-slip between reinforcement and concrete. Strains distribution along the beam thickness within the framework of the classical beam theory based on the hypothesis of plane section has the following form

$$
\varepsilon(x, z)=e(x)+z \kappa(x), \quad e(x)=\frac{d u}{d x}, \quad \kappa(x)=-\frac{d^{2} w}{d x^{2}},
$$

where $\varepsilon(x, z)$ is the longitudinal strain in the beam, $e(x)$ is the middle surface strain, $\kappa(x)$ is the middle surface curvature, $u(x)$ is the longitudinal displacement, and $w(x)$ is the deflection of the middle surface. Under the flexural loading, tensile and compression strains arise in the beam. The interface between these two states where deformation equals zero is denoted by $z_{n}(x)$. According to $(1) z_{n}(x)=-e(x) / \kappa(x)$. The physical relationships between stresses and strains can be expressed as $\sigma_{c}(x, z)=g_{c}^{ \pm}(\varepsilon), \sigma_{r}(x, z)=g_{r}(\varepsilon)$, where the superscript "+" refers to the relationships for the area with $\varepsilon>0$, " -" - for the area with $\varepsilon<0, g_{c}^{ \pm}$and $g_{r}$ are approximating functions for $\sigma-\varepsilon$ diagrams of concrete and steel, respectively. The least-squares method (LSM) is used for the curve fitting of sigma-epsilon diagrams hereinafter.

Damage evolution due to formation and propagation of cracks. To take into account the effect of tension and compression, it is necessary to consider strains on the interval $\varepsilon^{-} \leqslant$ $\varepsilon \leqslant \varepsilon^{+}$, where $\varepsilon^{ \pm}$are a limit tension $(+)$and compression $(-)$strains, different for each beam material, $\sigma^{ \pm}$are corresponding limit stresses [14]. The damage evolution mechanism of concrete is associated with the formation and propagation of flexural cracks. The part of the cross section where longitudinal strains and stresses exceed their limits is assumed to be completely damaged as shown in Fig. 3. The beam is discretized along its length with a finite number of nodes. Only cross sections associated with the discretization nodes are considered. The evolution of the damaged area in cross sections with the progressive load $P$ increasing on the value $\Delta P$ is modeled according to the following algorithm:

1) $e(x)$ and $\kappa(x)$ are found taking into account only the non-damaged areas at each load step. Coordinates $h_{c}$ and $h_{t}$ (along the $z$-axis) separate damaged from non-damaged regions in the areas of compression and tension, respectively (Fig. 3).

2) The part of the cross section for which $\varepsilon(x, z)>\varepsilon^{+}$or $\varepsilon(x, z)<\varepsilon^{-}$is not included in calculations. The new coordinates of $h_{c}$ and $h_{t}$ are calculated.

3) The big difference between $h_{c}$ and $h_{t}$ calculated and those on the previous loading step may distort the values of $e(x), \kappa(x)$, and $w$. In order to fix that, $e(x)$ and $\kappa(x)$ are recalculated at the same load, taking into account $h_{c}$ and $h_{t}$ already found. Then the new values $h_{c}$ and $h_{t}$ are calculated and the difference between determined and their previous values is found. This 
process continued until the absolute of this difference became smaller $\delta \cdot 2 h$, where $\delta$ is a small constant.

Let $h_{1}, h_{2}$ be the coordinates along the $z$-axis of the top and bottom boundaries of a cross section in the tension zone where reinforcement is located (Fig. 1, right). Then:

1) If $h_{t} \geqslant h_{2}$ then the damaged area is below the reinforcement layer (see Fig. 3a) and

$$
\begin{gathered}
N(e, \kappa)=b \int_{h_{c}}^{z_{n}(x)} g_{c}^{-} d z+b \int_{z_{n}(x)}^{h_{1}} g_{c}^{+} d z+\int_{h_{1}}^{h_{2}}\left(b_{c} g_{c}^{+}+b_{r} g_{r}\right) d z+b \int_{h_{2}}^{h_{t}} g_{c}^{+} d z=N(x), \\
M(e, \kappa)=b \int_{h_{c}}^{z_{n}(x)} g_{c}^{-} z d z+b \int_{z_{n}(x)}^{h_{1}} g_{c}^{+} z d z+\int_{h_{1}}^{h_{2}}\left(b_{c} g_{c}^{+}+b_{r} g_{r}\right) z d z+b \int_{h_{2}}^{h_{t}} g_{c}^{+} z d z=M(x),
\end{gathered}
$$

where $b_{r}=b \frac{S_{r}}{S}, S$ is the square of the cross section beam part including reinforcement, $S_{r}$ is the square of the reinforcement section, $b_{c}=b-b_{r}$.

2) If $h_{1} \leqslant h_{t}<h_{2}$ then the damaged area is in the reinforcement layer (see Fig. 3b) and

$$
\begin{gathered}
N(e, \kappa)=b \int_{h_{c}}^{z_{n}(x)} g_{c}^{-} d z+b \int_{z_{n}(x)}^{h_{1}} g_{c}^{+} d z+b_{c} \int_{h_{1}}^{h_{t}} g_{c}^{+} d z+b_{r} \int_{h_{1}}^{h_{2}} g_{r} d z=N(x), \\
M(e, \kappa)=b \int_{h_{c}}^{z_{n}(x)} g_{c}^{-} z d z+b \int_{z_{n}(x)}^{h_{1}} g_{c}^{+} z d z+b_{c} \int_{h_{1}}^{h_{t}} g_{c}^{+} z d z+b_{r} \int_{h_{1}}^{h_{2}} g_{r} z d z=M(x) .
\end{gathered}
$$

3) If $h_{t}<h_{1}$ then the damaged area is above the reinforcing layer (see Fig. 3c) and

$$
\begin{gathered}
N(e, \kappa)=b \int_{h_{c}}^{z_{n}(x)} g_{c}^{-} d z+b \int_{z_{n}(x)}^{h_{t}} g_{c}^{+} d z+b_{r} \int_{h_{1}}^{h_{2}} g_{r} d z=N(x), \\
M(e, \kappa)=b \int_{h_{c}}^{z_{n}(x)} g_{c}^{-} z d z+b \int_{z_{n}(x)}^{h_{t}} g_{c}^{+} z d z+b_{r} \int_{h_{1}}^{h_{2}} g_{r} z d z=M(x) .
\end{gathered}
$$

For the sake of brevity, we will hereafter refer only to the first case of the formulas (2), (3). We assume that the beam failure occurs in one of the cases:

1) There is a cross section that has been completely damaged, i.e. $h_{c} \geqslant h_{t}$.

2) The structure is not able to take additional loads which is equivalent to the descending branch of $P-w$ curve. In such a case either the iterative process of solving the system of nonlinear algebraic equations (2) and (3) does not converge or curvature $\kappa(x)$ decreases at the next small increment $\Delta P$. In the last case, this behavior of the solution is nonphysical and is explained by the nonlinearity of the system of equations. There is a bifurcation of its solution.

All these cases occur when values of $P$ and corresponding $w$ are close to each other. That is why their appearance in the calculations can be considered as the failure of the beam. 


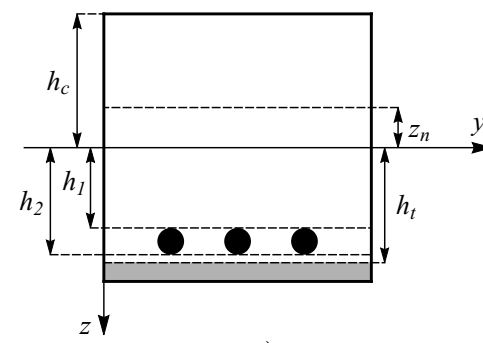

a)

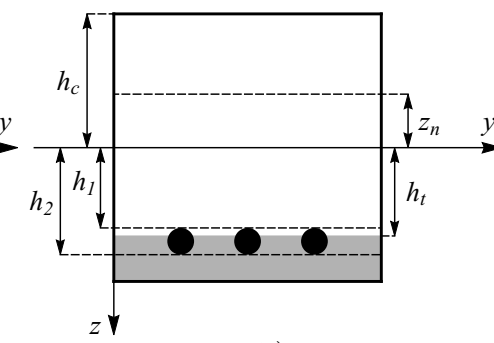

b)

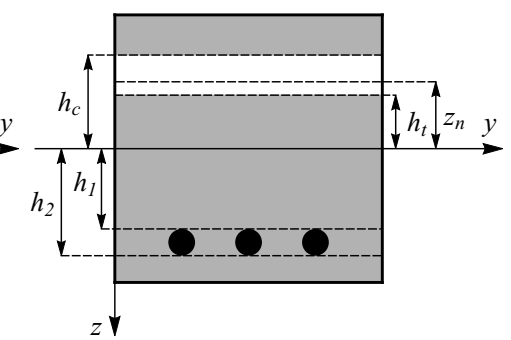

c)

Fig. 3. Cross sections in different cases of cracks propagation. The dark color denotes the completely damaged part of the section; dashed lines separate areas with the certain $\sigma-\varepsilon$ relationships

\section{Numerical iplementation of the mathematical model}

The quasi-static loading process with a small load increment is considered. It becomes necessary to repeatedly solve the nonlinear equations (2), (3). They are solved here using Newton's method [15]. The values $e$ and $\kappa$ are computed independently at each cross section, so it is convenient to use parallelizing to determine them. To determine $w(x)$ after $\kappa(x)$ and $e(x)$ have been found, it is necessary to solve the following boundary value problem

$$
\frac{d^{2} w}{d x^{2}}=-\kappa(x), \quad w(0)=w(l)=0 .
$$

For this purpose, the hp-version of the least-squares collocation (LSC) method is constructed, where piecewise polynomial functions are used to approximate solution $[15,16]$. The polynomials degree and grid refinement can be varied easily before running the program. The following equations are written out in each cell. The collocation equations provide $\frac{d^{2} w}{d x^{2}}=-\kappa(x)$ at several interior points of the cell. Continuity between solutions and their derivatives at the points separating adjacent cells is required in matching conditions. In addition, the boundary conditions are approximated at the points $x=0, l$. Cross sections are considered at the collocation points and $e(x)$ and $\kappa(x)$ are calculated there taking into account damaged area. The LSC method is effectively used in combination with the acceleration of the iterative process based on Krylov subspaces and parallelizing using OpenMP.

The bending of the concrete beam by a distributed load (case 1) and its four-point bending (case 2) is considered in the physically linear formulation with the known analytical solution [17] to verify the LSC method. Tab. 1 shows the corresponding numerical results, where $K$ is a polynomial degree, $\left\|E_{r}\right\|_{\infty}$ is the relative error in the infinity norm, $R$ is the convergence order. It can be seen that $R=2$ when $K=2,3$ and $R=4$ when $K=4,5$ in the case 1 . The value of $R \approx 2$ for any $K$ in the case 2 , since the third derivatives of the solution (the piecewise polynomial function of the order not greater than three) have a discontinuity in the points where concentrating loads are applied [17]. If the grid is chosen so that these points fall on the boundaries between the cells then the numerical solution accuracy is about $10^{-15}$ for $K \geqslant 3$.

\section{Concrete and steel stress-strain diagrams}

Experimental tests data of concrete tension and compression, steel reinforcements tension, and the four-point bending of $\mathrm{RC}$ beams ( $P-w$ diagram) are necessary to validate the mathematical model. Note that in practice such a complex of mechanical tests is rarely carried out in 
Table 1. Numerical results arising from the LSC method

\begin{tabular}{|c|c|c|c|c|c|c|c|c|}
\hline \multicolumn{9}{|c|}{ Case №1 } \\
\hline & \multicolumn{2}{|c|}{$K=2$} & \multicolumn{2}{|c|}{$K=3$} & \multicolumn{2}{|c|}{$K=4$} & \multicolumn{2}{|c|}{$K=5$} \\
\hline Grid & $E_{r} \|_{\infty}$ & $R$ & $E_{r} \|_{\infty}$ & $R$ & $E_{r} \|_{\infty}$ & $R$ & $E_{r} \|_{\infty}$ & $R$ \\
\hline 20 & $1.94 \cdot 10^{-3}$ & - & $6.43 \cdot 10^{-5}$ & - & $9.23 \cdot 10^{-8}$ & - & $1.77 \cdot 10^{-8}$ & - \\
\hline 40 & $4.85 \cdot 10^{-4}$ & 2.00 & $1.60 \cdot 10^{-5}$ & 2.01 & $5.76 \cdot 10^{-9}$ & 4.00 & $1.10 \cdot 10^{-9}$ & 4.01 \\
\hline 80 & $1.21 \cdot 10^{-4}$ & 2.00 & $4.01 \cdot 10^{-6}$ & 2.00 & $2.99 \cdot 10^{-10}$ & 4.31 & $6.97 \cdot 10^{-11}$ & 3.98 \\
\hline \multicolumn{9}{|c|}{ Case №2 } \\
\hline & \multicolumn{2}{|c|}{$K=2$} & \multicolumn{2}{|c|}{$K=3$} & \multicolumn{2}{|c|}{$K=4$} & \multicolumn{2}{|c|}{$K=5$} \\
\hline Grid & $E_{r} \|_{\infty}$ & $R$ & $E_{r} \|_{\infty}$ & $R$ & $\mid E_{r} \|_{\infty}$ & $R$ & $\mid E_{r} \|_{\infty}$ & $R$ \\
\hline 20 & $1.97 \cdot 10^{-3}$ & - & $8.22 \cdot 10^{-5}$ & - & $7.76 \cdot 10^{-6}$ & - & $4.29 \cdot 10^{-5}$ & - \\
\hline 40 & $4.86 \cdot 10^{-4}$ & 2.02 & $2.02 \cdot 10^{-5}$ & 2.02 & $2.46 \cdot 10^{-6}$ & 1.66 & $1.00 \cdot 10^{-5}$ & 2.10 \\
\hline 80 & $1.22 \cdot 10^{-4}$ & 1.99 & $5.05 \cdot 10^{-6}$ & 2.00 & $4.72 \cdot 10^{-7}$ & 2.38 & $2.58 \cdot 10^{-6}$ & 1.95 \\
\hline
\end{tabular}

full under strictly controlled laboratory conditions. For instance, in the description of bending experiments [18], whose data are used here, there are given: geometrical dimensions of the beam $2 h=46.38 \mathrm{~cm}, b=25.756 \mathrm{~cm}, l=457.2 \mathrm{~mm}$; the number of reinforcement elements -3 pcs., with the cross section radius of $7.98 \mathrm{~cm}$; distance from the supports to the load application points $a=152.4 \mathrm{~cm}$; the concrete compressive strength $f_{c}=-32 \mathrm{MPa}$; the average values of the steel tensile yield strength $\sigma_{y}=473 \mathrm{MPa}$ and the elastic modulus $E=236 \mathrm{GPa}$.

Concrete. Uniaxial concrete compression diagrams have a clear-cut nonlinear behavior as early as the region of average strains [14] (Fig. 4a). Diagram constructed by the method described in [11] at $f_{c}=\sigma_{c}^{-}=-32 \mathrm{MPa}$ (experimental data) and $\varepsilon_{c}^{-}=-0.003$ is taken as the concrete deformation law in the case №1. The diagram of concrete deformation with data from [11] is approximated in case №2, i.e. $f_{c}=\sigma_{c}^{-}=-33.1 \mathrm{MPa}$ and $\varepsilon_{c}^{-}=-0.003$. It was assumed that $E_{c_{1}}^{+}=4733 \sqrt{\left|f_{c}\right|} \mathrm{MPa}, \sigma_{c}^{+}=0.62 \sqrt{\left|f_{c}\right|} \mathrm{MPa}$ in all cases [11].

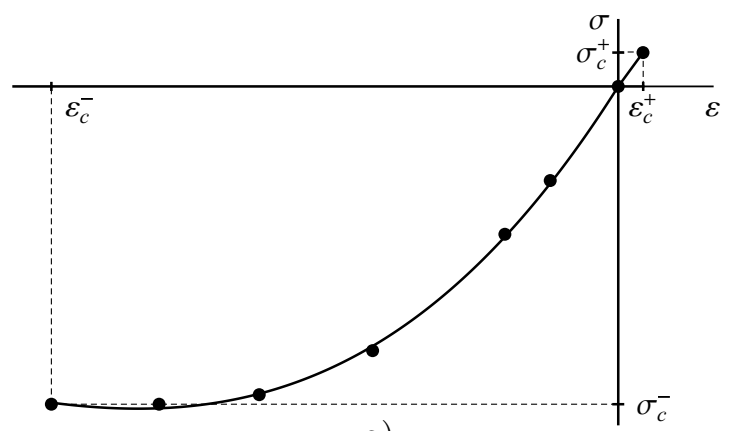

a)

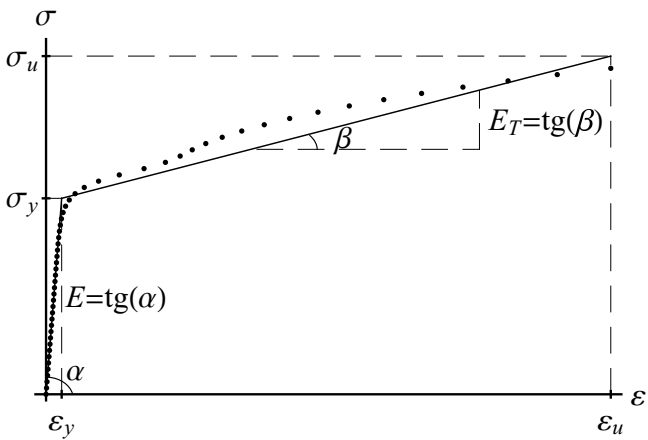

b)

Fig. 4. Discrete (symbol •) $\sigma-\varepsilon$ diagrams of concrete and steel and its approximations (solid lines)

We approximate the concrete $\sigma-\varepsilon$ diagram by the following relationships

$$
\begin{aligned}
& g_{c}^{+}(\varepsilon)=E_{c_{1}}^{+} \varepsilon, \quad \varepsilon \geqslant 0, \\
& g_{c}^{-}(\varepsilon)=E_{c_{1}}^{-} \varepsilon+E_{c_{2}}^{-} \varepsilon^{2}+E_{c_{3}}^{-} \varepsilon^{3}, \quad \varepsilon \leqslant 0 .
\end{aligned}
$$

Tab. 2 shows the approximation coefficients of the concrete tension and compression $\sigma-\varepsilon$ 
diagrams and $\varepsilon_{c}^{-}, \varepsilon_{c}^{+}, \sigma_{c}^{+}, \sigma_{c}^{-}$in different cases.

Table 2. Approximation coefficients and limits of the concrete $\sigma-\varepsilon$ diagrams

\begin{tabular}{|c|c|c|c|c|c|c|c|c|}
\hline Case & \multicolumn{3}{|c|}{ Tension } & \multicolumn{5}{c|}{ Compression } \\
\hline & $E_{c_{1}}^{+}, \mathrm{GPa}$ & $\varepsilon_{c}^{+}$ & $\sigma_{c}^{+}, \mathrm{MPa}$ & $E_{c_{1}}^{-}, \mathrm{GPa}$ & $E_{c_{2}}^{-}, \mathrm{GPa}$ & $E_{c_{3}}^{-}, \mathrm{GPa}$ & $\varepsilon_{c}^{-}$ & $\sigma_{c}^{-}, \mathrm{MPa}$ \\
\hline №1 & 26.7 & $1.31 \mathrm{e}-4$ & 3.52 & 31.3 & $9.51 \mathrm{e}+3$ & $8.76 \mathrm{e}+5$ & $-3.0 \mathrm{e}-3$ & -32 \\
\hline №2 & 27.1 & $1.31 \mathrm{e}-4$ & 3.58 & 31.2 & $8.96 \mathrm{e}+3$ & $7.38 \mathrm{e}+5$ & $-3.0 \mathrm{e}-3$ & -33.1 \\
\hline
\end{tabular}

Reinforcement. We approximate the steel tension diagram by the following relationships

$$
g_{r}(\varepsilon)= \begin{cases}E_{r_{1}} \varepsilon, & \varepsilon \leqslant \varepsilon_{y} \\ E_{r_{0}}+E_{r_{h}} \varepsilon, & \varepsilon>\varepsilon_{y}\end{cases}
$$

where $\varepsilon_{y}$ is the strain value corresponding to the steel yield strength $\sigma_{y}$. Here $E_{r_{0}}=\sigma_{y}-$ $\sigma_{y} E_{r_{h}} / E_{r_{1}}$. Let $\varepsilon_{u}$ be the strain value corresponding to the $\sigma_{u}, E$ and $E_{T}$ be the elastic and strain hardening modulus, respectively. There are only known $\sigma_{y}, E$, and $\sigma_{u}$ from the experiment [18]. For this reason we consider several cases with the different $E_{T}$. Approximation coefficients of the steel tension $\sigma-\varepsilon$ diagrams are given in Tab. 3. Piecewise linear approximation of the $\sigma-\varepsilon$ diagram with the values $\sigma_{y}, E_{r_{1}}=E$ taken from experiment and different $E_{r_{h}}=E_{T}$ is considered in the cases №1-3. Case №4 corresponds to the piecewise linear approximation of the data taken from [11]. In the case №5 the $\sigma-\varepsilon$ curve is also approximated by the piecewise linear function based on the following considerations. All reinforcement is Grade 60 in [18]. It corresponds to the yield strength $\sigma_{y}=60 \mathrm{psi}=413 \mathrm{MPa}$. Mechanical properties of such reinforcement are described by the standard ASTM A706 presented in american building regulations ACI. The required material (carbon steel SA 537) is determined by the standard ASTM A706. We get its diagram by the method from [19] (Fig. 4b). Tab. 4 shows the contracted notations of the $\sigma-\varepsilon$ concrete and reinforcement diagrams used.

Table 3. Yield strength and approximation coefficients of the reinforcement $\sigma-\varepsilon$ diagrams

\begin{tabular}{|c||c|c|c|}
\hline \multicolumn{1}{|c||}{ Case } & \multicolumn{3}{c|}{ Tension } \\
\hline & $E_{r_{1}}, \mathrm{GPa}$ & $E_{r_{h}}, \mathrm{MPa}$ & $\sigma_{y}, \mathrm{MPa}$ \\
\hline №1 & 236 & 2360 & 473 \\
\hline №2 & 236 & 236 & 473 \\
\hline №3 & 236 & 23.6 & 473 \\
\hline №4 & 200 & 20.0 & 413 \\
\hline №5 & 200 & 3792 & 413 \\
\hline
\end{tabular}

Table 4. Stress-strain relationships notations

\begin{tabular}{|c|c|c|}
\hline Concrete & $\begin{array}{c}\text { Paper [11], } \\
f_{c}=32 \mathrm{MPa}\end{array}$ & $\begin{array}{c}\text { Paper [11], } \\
f_{c}=33.1 \mathrm{MPa}\end{array}$ \\
\hline$E_{r_{1}}=236 \mathrm{e}+3, \sigma_{y}=473, E_{r_{h}}=23.6 \mathrm{MPa}$ & $(1,1)$ & $(1,2)$ \\
\hline$E_{r_{1}}=236 \mathrm{e}+3, \sigma_{y}=473, E_{r_{h}}=236 \mathrm{MPa}$ & $(2,1)$ & - \\
\hline$E_{r_{1}}=236 \mathrm{e}+3, \sigma_{y}=473, E_{r_{h}}=2360 \mathrm{MPa}$ & $(3,1)$ & - \\
\hline$E_{r_{1}}=200 \mathrm{e}+3, \sigma_{y}=413, E_{r_{h}}=20 \mathrm{MPa}$ & - & $(4,2)$ \\
\hline$E_{r_{1}}=200 \mathrm{e}+3, \sigma_{y}=413, E_{r_{h}}=3792 \mathrm{MPa}$ & - & $(5,2)$ \\
\hline
\end{tabular}




\section{Comparison with experimental data and $3 \mathrm{D}$ simulation}

The following geometric dimensions of the beam $2 h=45.72 \mathrm{~cm}, b=25.4 \mathrm{~cm}, l=457.2 \mathrm{~cm}$ are used for an adequate comparison with the results of [11] in calculations with notations $(1,2)$, $(4,2)$, and $(5,2)$. Geometric dimensions from the experiment are taken in the other cases. The distance from the bottom edge of the beam to the center of the reinforcement section is $6.35 \mathrm{~cm}$ by the analogy with [11] in all cases. The load increment $\Delta P$ is taken to be equal to $50 \mathrm{~N}$ until the yielding of the reinforcing steel and then is switched to $5 \mathrm{~N}$.

The beam in the experiment contains shear reinforcement in the form of a thin U-stirrups [18], which were not taken into account in this paper. The dominant failure mechanism in [18] was the propagation of transverse cracks in the tensile zone of concrete. Therefore, shear reinforcement in this case has not a significant effect on the beam SSS. It should be noted that the failure mode of the RC beam (along a normal section and/or along an oblique section) depends on an amount of longitudinal and shear reinforcement.

Fig. 5 shows the results of the experiment [18], calculations carried out using ANSYS [11] and within the framework of the model proposed here. Different deformation regions are marked with Roman numerals: I - before the appearance of the first crack, II - from the moment of the appearance of the first crack until the beginning of reinforcement yield, III - from the moment of reinforcement yield to the failure. The transition zones between different regions are marked in gray. Tab. 5 demonstrates some key quantitative characteristics of the experiment and calculations.

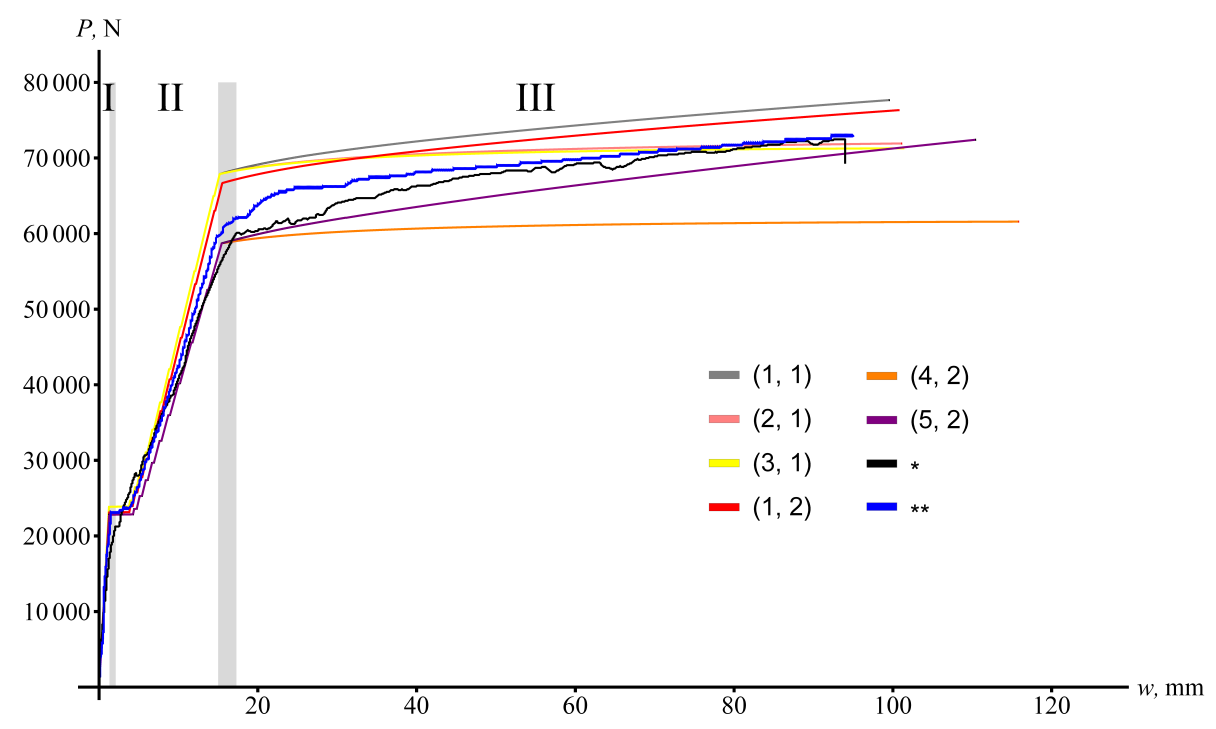

Fig. 5. Experimental data $(*)[18]$, ANSYS (**) [11] and calculations in the proposed model

We can make the following conclusions from the above results.

1) On the region I the calculations within this model practically agree with the calculations on ANSYS [11]: $P_{c r}$ differs by no more than $1.5-3 \%$. In the experiment, the slope of the $P-w$ curve is lower and the moment of crack initiation is earlier (Fig. 5 and Tab. 5).

2) On the region II the jumps of the deflections at $P_{c r}$ (Fig. 5) and the slopes of the $P-w$ curves in calculations with parameters from [11] (cases $(4,2)$ and $(5,2))$ and in ANSYS are almost the same. The slopes of the $P-w$ curves in calculations with parameters from [18] are slightly larger compared to ones obtained in ANSYS [11] and experiment [18] (the difference is no more than $15 \%$ relative to $P_{y}$ ) by virtue of the fact that $E_{r_{1}}$ was larger than in [11]. 
Table 5. Comparison of calculation and experimental quantitative characteristics, where $P_{c r}$ is the load at first cracking, $P_{y}$ is the load when steel yielding occurs, $P_{\max }$ is the failure load, $w_{\max }$ is the maximum deflection

\begin{tabular}{|c|c|c|c|c|}
\hline$P-w$ curve & $P_{c r}, \mathrm{~N}$ & $P_{y}, \mathrm{~N}$ & $P_{\max }, \mathrm{N}$ & $w_{\max }, \mathrm{cm}$ \\
\hline Experiment $[18]$ & $\sim 20000$ & 59047 & 72550 & 9.27 \\
\hline ANSYS [11] & 23227 & 59626 & 72870 & 9.49 \\
\hline$(1,1)$ & 23900 & 67900 & 77655 & 9.94 \\
\hline$(1,2)$ & 23150 & 66700 & 76320 & 10.07 \\
\hline$(2,1)$ & 23900 & 67900 & 71920 & 10.10 \\
\hline$(3,1)$ & 23900 & 67900 & 71280 & 10.13 \\
\hline$(4,2)$ & 22850 & 58750 & 61580 & 11.57 \\
\hline$(5,2)$ & 22850 & 58750 & 72405 & 11.03 \\
\hline
\end{tabular}

3) On the region III the slope of the $P-w$ curve in the reinforcement yielding zone and $P_{\max }$ strongly depend on $E_{T}$. The $P-w$ curve in case $(4,2)$ lies lower than the corresponding curve obtained in ANSYS.

Table 6 shows the dependence of the values $w_{\max }$ and $P_{\max }$ on the values of $\delta$. The obtained values of $w_{\max }$ may turn out to be overrated in the case of insufficiently small values $\delta$. Nevertheless, a significant increase of $w$ occurs with the last few increments of $\Delta P$. However, a growth rate of $w$ increases rapidly at loads close to $P_{\max }$ even with a small value of $\delta$. It has been found that a further decrease of $\delta<10^{-4}$ has not led to significant changes in the solution of the problem in this study.

Table 6. Dependence of the results on values $\delta$

\begin{tabular}{|c||c|c||c|c||c|c|}
\hline \multirow{2}{*}{ case } & \multicolumn{2}{|c|}{$\delta=10^{-2}$} & \multicolumn{2}{c|}{$\delta=10^{-3}$} & \multicolumn{2}{c|}{$\delta=10^{-4}$} \\
\cline { 2 - 7 } & $w_{\max }, \mathrm{cm}$ & $P_{\max }, \mathrm{N}$ & $w_{\max }, \mathrm{cm}$ & $P_{\max }, \mathrm{N}$ & $w_{\max }, \mathrm{cm}$ & $P_{\max }, \mathrm{N}$ \\
\hline$(1,1)$ & 11.80 & 77690 & 10.12 & 77675 & $\mathbf{9 . 9 4}$ & $\mathbf{7 7 6 5 5}$ \\
\hline$(1,2)$ & 11.29 & 76345 & 10.16 & 76330 & $\mathbf{1 0 . 0 7}$ & $\mathbf{7 6 3 2 0}$ \\
\hline$(2,1)$ & 18.16 & 71940 & 10.82 & 71935 & $\mathbf{1 0 . 1 0}$ & $\mathbf{7 1 9 2 0}$ \\
\hline$(3,1)$ & 20.86 & 71290 & 20.86 & 71290 & $\mathbf{1 0 . 1 3}$ & $\mathbf{7 1 2 8 0}$ \\
\hline$(4,2)$ & 31.13 & 61590 & 31.13 & 61590 & $\mathbf{1 1 . 5 7}$ & $\mathbf{6 1 5 8 0}$ \\
\hline$(5,2)$ & 12.08 & 72450 & 11.15 & 72430 & $\mathbf{1 1 . 0 3}$ & $\mathbf{7 2 4 0 5}$ \\
\hline
\end{tabular}

The CPU time within the proposed model ranged from several tens of seconds to 20 minutes on a computer Intel Core i5-8265U CPU $1.6 \mathrm{GHz}, 4$ Cores, DIMM DDR4-2400 1200 MHz 8 Gb depending on the grid size (from 9 to 27 cells) and the degree of approximating polynomial (polynomials of the 2nd, 4th, and 6th degrees) in the LSC method. It has been found that the results obtained and compared here are in a good agreement with each other.

\section{Conclusions}

The developed mathematical model and numerical algorithm have shown their effectiveness in modelling and simulation of $\mathrm{RC}$ beams under four-point bending. To model RC bending up to failure, several features of RC deformation were taken into account, such as nonlinear stress-strain relationships, multi-modulus concrete behavior, and damage evolution caused by the formation and propagation of cracks. The proposed numerical algorithm combines the Newton method, LSM, verified hp-version of the LSC method of increased accuracy, and modern methods of 
accelerating the iterative process. Performed calculations demonstrate the high speed of solving the problem and satisfactory agreement with experimental data and three-dimensional modelling results. The influence of various deformation laws and the method of their approximation, as well as the parameter $\delta$ on the results of numerical simulation has been shown.

The research was carried out within the state assignment of Ministry of Science and Higher Education of the Russian Federation (project Nos. 121030500137-5 and AAAA-A19119051590004-5).

\section{References}

[1] V.N.Baikov, E.E.Sigalov, Reinforced Concrete Structures. General course, Stroyizdat, Moscow, 1991 (in Russian).

[2] J.C McCormac, Design of Reinforced Concrete, 10th edition, John Wiley \& Sons, New York, 2015.

[3] V.G.Evstifeev, Reinforced Concrete Structures. Calculation and Design, Ivan Fedorov, Saint-Petersburg, 2005 (in Russian).

[4] SP 63.13330.2012 Concrete and Reinforced Concrete Structures. General Provisions, FAU FCC, Moscow, 2012 (in Russian).

[5] GOST 8829-2018 Prefabricated Construction Concrete and Reinforced Concrete Products. Load Testing Methods. Rules for Assesment of Strength, Rigidity and Crack Resistance, FGUP STANDARTINFORM, Moscow, 2019 (in Russian).

[6] Building Code Requirements for Structural Concrete (ACI 318-08) and Commentary, American Concrete Institute, Farmington Hills, 2008.

[7] Eurocode 2: Design of Concrete Structures - Part 1-1: General Rules and Rules for Buildings, British Standards Institution, United Kingdom, 2004.

[8] G Monti, E.Spacone, Reinforced concrete fiber beam element with bond-slip, J. Struct. Eng., 126(2000), no. 6, 654-661.

[9] D.Floros, O.A.Ingason, Modelling and Simulation of Reinforced Concrete Beams, Master's thesis, Chalmers University of Technology, Göteborg, 2013.

[10] V.V.Adishchev, V.V.Maltsev, Application of nonlinear charts of deformation of concrete for calculation of the stress-straned state in the reinforced concrete beam by the numerical and analytical method, News of HEI. Construction, 2017, no. 1, 5-17 (in Russian).

[11] A.J.Wolanski, Flexural Behavior of reinforced and prestressed concrete beams using finite element analysis, Master's thesis, Marquette University, Milwaukee, 2004.

[12] A.V.Lukin, V.S.Modestov, Finite element modeling and an analysis of the stress-strain state of reinforced concrete structures, St. Petersburg Polytechnic University Journal: Physics and Mathematics, 2014, no. 3(201), 35-46 (in Russian).

[13] A.S.Samoshkin, V.M.Tikhomirov, Mathematical model of reinforced concrete deformation with considering contact interaction of its structural components, Computat. Technolog., 22(2017), special issue no. 1, 75-86 (in Russian).

[14] Y.V.Nemirovsky, A.I.Boltaev, Strain diagrams of concrete and reinforced concrete, Bulletin of BSTU named after V.G. Shukhov, 2015, no. 6, 125-129 (in Russian). 
[15] E.V.Amelina etc., Nonlinear deformation of carbon fiber reinforced plastics: experiment, model, and simulation, Computat. Technolog., 20(2015), no. 5, 27-52 (in Russian).

[16] V.A. Belyaev, Solving a Poisson equation with singularities by the least-squares collocation method, Numerical Analysis and Applications, 13(2020), no. 3, 207-218.

DOI: $10.1134 / \mathrm{s} 1995423920030027$

[17] S.P.Timoshenko, Strength of Materials. Part 1. Elementary theory and problems, 2nd edition, D. Van Nostrand Company, Toronto et al., 1940.

[18] C.M.Foley, E.R.Buckhouse, Strengthening Existing Reinforced Concrete Beams for Flexure Using Bolted External Structural Steel Channels, Research report, Marquette University, College of Engineering, Dept. of Civil and Environmental Engineering, Milwaukee, 1998.

[19] ASME Boiler and Pressure Vessel Code. Section VIII, Division 2, The American Society of Mechanical Engineers, New York, 2015.

\title{
Моделирование деформирования и разрушения железобетонных балок при четырехточечном изгибе
}

\author{
Василий А. Беляев \\ Институт теоретической и прикладной механики им. С. А. Христиановича СО РАН \\ Новосибирск, Российская Федерация \\ Артем И. Болтаев \\ Новосибирский государственный университет \\ Новосибирск, Российская Федерация \\ ООО "Исследовательский Комплекс Центра Технологического Обеспечения" \\ Новосибирск, Российская Федерация \\ Лука С. Брындин \\ Институт теоретической и прикладной механики им. С. А. Христиановича СО РАН \\ Новосибирск, Российская Федерация \\ Новосибирский государственный университет \\ Новосибирск, Российская Федерация \\ Сергей К. Голушко \\ Арсений Г. Горынин \\ Новосибирский государственный университет \\ Новосибирск, Российская Федерация \\ Василий П. Шапеев \\ Институт теоретической и прикладной механики им. С. А. Христиановича СО РАН \\ Новосибирск, Российская Федерация \\ Новосибирский государственный университет \\ Новосибирск, Российская Федерация

\begin{abstract}
Аннотация. Разработана и исследована новая математическая модель четырехточечного изгиба железобетона с учетом разносопротивляемости бетона растяжению-сжатию, физической нелинейности и разрушения. Предложен алгоритм численной реализации модели. Соответствующая краевая задача решалась hр-вариантом метода коллокации и наименьших квадратов в комбинации с ускорением итерационного процесса, основанным на подпространствах Крылова, и распараллеливанием. Исследовано влияние параметров математической модели на результаты численного моделирования. Проведено сравнение результатов расчетов с экспериментальными данными и трехмерным моделированием и показано удовлетворительное согласие с ними.
\end{abstract}

Ключевые слова: железобетон, физическая нелинейность, четырехточечный изгиб, разносопротивляемость, разрушение, трещина, моделирование. 